\title{
ПІДГОТОВКА МАЙБУТНЬОГО ВЧИТЕЛЯ ПОЧАТКОВОЇ ШКОЛИ ДО САМОРЕАЛІЗАЦЇ̈ В СУСПІЛЬСТВІ СПОЖИВАННЯ
}

\begin{abstract}
Семенова М. О.
кандидат педагогічних наук, доцент, доцент кафедри педагогіки, психології, початкової освіти та освітнього менеджменту, Комунальний заклад «Харківська гуманітарно-педагогічна академія» Харківської обласної ради, м. Харків, Україна
\end{abstract}

Оскільки Україна стала на шлях ринкових реформ, ией процес зачіпає й освіту, щуо здебільшого перетворюється на ринково орієнтовану, причому в иифровому середовищі. У таких умовах фахова підготовка майбутнього вчителя початкових класів набуває нового сенсу, хоча його підготовка до самореалізації є основним завданням вищої освіти всіх рівнів.

Ключові слова: майбутній учитель, самореалізачія особистості, ринкова економіка, суспільство споживання, цифрова культура.

As Ukraine embarks on the path of market reforms, this process also affects education, which for the most part turns into market-oriented education, and in a digital environment. In such conditions, the professional training of future primary school teachers acquires a new meaning, although his preparation for self-realization is the main task of higher education at all levels.

Key words: Future teacher, self-realization of the individual, market economy, consumer society, digital culture.

Підготовка вчителя, якого ми називаємо «майбутнім» є складною проблемою наслідок того, що соціальне життя суспільства постійно змінюється. У зв'язку з цим, хто обрав професію вчителя, має навчатися впродовж усього життя, щоб успішно самореалізуватися, тобто найповніше використати власні творчі здібності, для чого потрібна внутрішня робота над собою - саморозвиток, самоздійснення, самовиховання.

Із гуманістичної психології, основні ідеї якої запропонував А. Маслоу, випливає питання самореалізації, яке розглядали Г. Батіщев, Д. Леонтьєв, О. Лосєв, В. Петровський, В. Роменець, С. Рубінштейн, Т. Тираненко та ін. А. Маслоу, думку якого ми поділяємо, уважав, що від природи в кожній людині закладені потенційні можливості для по- 
зитивного зростання й самовдосконалення, а «творчість - універсальна функція людини, що веде до всіх форм самовираження» [5, с. 486]. Це насамперед стосується майбутнього вчителя початкової школи, який має підготуватися до професійної самореалізації, а саме до самореалізації у своїх учнях, радіти їх успіхам. Якщо людина зробила власний вибір професії вчителя початкових класів, то у процесі навчання треба сприяти іiі особистісному зростанню. Тоді майбутній педагог стане тим, на що він здатний, буде прагнути досконалості.

Про освіту впродовж життя та вживання заходів щодо забезпечення безперервності, подолання кризи в освіті, пов'язаною з COVID-19, наголошується в документі 2020 р. під егідою ЮНЕСКО «Концептуальна записка: Освіта в епоху і в наступний період». У документі наголошується, що освіта є основним правом людини, «від якого безпосередньо залежить реалізація всіх інших прав людини», «основа для справедливого, рівноправного, інклюзивного та мирного суспільства». Серед стратегічних рекомендацій нової кампанії «Врятуємо наше майбутнє» розглянемо таку: «переосмислення освіти і прискорення позитивних перетворень в викладанні та навчанні» [4, с. 28]. Значна увага приділяється використанню таких технологій, які забезпечать безперервність навчання. Це доступ до електронних засобів навчання вчителів, школярів і батьків.

Насамперед учителі під час фахової підготовки мають навчитися цифровій культурі. За С. Доценко, розвиток цифрової інфраструктури, перехід на мережеві принципи комунікації, персоналізація Інтернету чинники, що змінюють етичні принципи й засади соціокультурної взаємодії. Посилаючись на О. Мурашкевича й О. Черних, вона дає визначення цифрової культури як сукупності компетенцій, що «характеризують здатність використання інформаційно-комунікаційних технологій для комфортного життя в цифровому середовищі, для взаємодії з суспільством та вирішення цифрових завдань у професійній діяльності» [1, с. 31]. Дійсно, сучасна початкова школа вже проводить Online уроки внаслідок карантину з COVID-19. Це вимагає від учителя оволодінням цифровою культурою як необхідною складовою його підготовки, умовою самореалізації.

Погоджуємося з М. Каку, який підкреслює, що людина постійно змінюється, удосконалюється ії діяльність, відбувається інтенсивний розвиток науки. Завдяки нанотехнологіям людина наближається до 
створення штучного інтелекту, однак це складне завдання, бо для цього машині потрібен здоровий глузд, на що здатна поки що тільки людина. Експерти вважають, що трансформація освіти має відбуватися в напрямі розвитку критичного мислення, навчати здатності до адаптації, роботі в команді та емоційному лідерству. На відміну від тварин «людина має добре розвинене почуття майбутнього й постійно складає плани. У голові кожного з нас безперервно моделюється майбутня реальність. Ми здатні складати плани, що простягаються далеко за межи нашого власного життя», причому саме для планування майбутнього потрібен здоровий глузд, інтуїтивне розуміння, що є можливим, а що - ні, конкретні стратегії досягнення конкретних цілей [3, с. 193], критичне мислення.

Привертає увагу й те, що освіта трансформується в новій соціальній реальності. Розвиток ринкових відносин спричиняє творення суспільства споживання, яке певною мірою копіює індивідуалістичну традицію культури США, споживання ж обумовлено не тільки й не стільки базовими потребами, а символічним смислом, що культура суспільства вкладає в речі. Бурхливий розвиток інформаційних технологій сприяв глобалізації споживання, що не оминуло й освіту, на яку вплинула стратегія Свроінтеграції. За даними Інтернету, у Харкові нині працює понад 48 приватних дитячих садочків, 17 приватних шкіл, а якщо враховувати філіали, то 28. Зростання кількості таких навчальних закладів свідчить про бажання батьків задовільнити індивідуальні потреби в навчанні власних дітей. Це означає, що майбутні вчителі мають навчитися ефективно працювати в умовах ринкової економіки.

Підкреслимо, що у США поряд з тенденцією до асиміляції різних етнічних груп простежується тенденція — розглядати країну не як «плавильний котел», а як «багатошаровий пиріг», «культурну мозаїку», в Україні не звертається увага на етнічну різноманітність, що відбивається й на освіті. Як зазначає В. Ільїн, роль етнічного чинника в споживанні зростає. Додамо, що «через споживання своєї етнічної приналежності найчастіше простежується в ситуації етнічних конфліктів чи напруженості в міжетнічних відносинах» [2, с. 177].

На нашу думку, в україномовних закладах освіти майбутніх учителів початкових класів доцільно знайомити з фольклором та етнографією свого краю, однак із навчальних програм багатьох ЗВО вилучено навіть курс етнопедагогіки. Добре, що з традиційною народною куль- 
турою можна ознайомитись в Інтернеті, однак бажано, щоб майбутньому вчителю пояснили витоки такої культури та їі досягнення. На кафедрі культурологічних дисциплін та образотворчого мистецтва факультету фізичного виховання та мистецтв майбутніх бакалаврів культурології знайомлять із основами фольклорної практики.

Нині етнічна культура стає модною, бо в Україні, як і в багатьох інших країнах, «почав розвиватися бізнес, пов'язаний із культивуванням у споживачів тяги до символів етнічної приналежності (національна їжа, елементи традиційного одягу, ремісничі вироби й т. п.)», що є тенденцією до зростання ролі етнічного чинника у споживанні [2, с. 176], навіть у кількох дитячих музичних школах нашого міста останнім часом з'явилися фольклорні гурти, які опановують музичний фольклор поряд iз класичною музичною освітою (ДМШ 3, № 4, № 7). Цього бажають батьки дітей, а керівництво підтримує їх зацікавленість у вияві етнічної приналежності та вивченні української народної культури.

Отже, самореалізація майбутнього вчителя початкових класів залежить від набутої цифрової культури й уміння працювати наполегливо й самостійно, а також від якісної фахової підготовки, що має враховувати потреби суспільства споживання, у тому числі й етнічний чинник.

\section{Список використаних джерел:}

1. Доценко С. О. Цифрова культура майбутнього викладача. Традиційна культура в умовах глобалізації: синергія традиції та новації. Матеріали науковопрактичної конференції (Харків, 21-22 червня 2019 року). Харків : Друкарня Мадрид, 2019. С. 31-34.

2. Ильин В. И. Поведение потребителей : учеб. пособие. Санкт-Петербург : Питер, 2003. 232 с.

3. Каку М. Физика будущего. пер. с англ. 6-е изд. Москва : Альпина нон фикшн, 2019. 736 с.

4. Концептуальная записка: Образование в эпоху COVID-19 и в последующий период. ООН. Резюме. Август 2020 года. 32 c. URL: https://www. un.org/sites/un2.un.org/files/policy_brief__education_during_covid-19_and_ beyond_russian.pdf (дата звернення: 07.10.2012)

5. Хьел Л. А., Зиглер Д. Дж. Теории личности : 3-е изд. Санкт-Петербург : Питер, 2011. 607 с. 